\title{
Effect of lactation period on the fatty acid composition in mares' milk from different breeds
}

\author{
Renata Pietrzak-Fiećko', Ryszard Tomczyński² and Stefan S. Smoczyński \\ ${ }^{1}$ Chair of Commodities and Food Analysis, Faculty of Food Science, University of Warmia and Mazury in Olsztyn, \\ Olsztyn, Poland, ${ }^{2}$ Chair of Horse Breeding and Riding, Faculty of Animal Bioengineering, University of Warmia and \\ Mazury in Olsztyn, Olsztyn, Poland
}

\begin{abstract}
Analyses were carried out on the fatty acid composition of milk fat originating from mares of three breeds: Polish Cold-Blooded, Wielkopolski and Konik Polski. Milk was collected from mares in the early, mid and late lactation. Determination of fatty acids was conducted with the gas chromatography method. The analysis of the fatty acid composition demonstrated that over the entire lactation period unsaturated fatty acids (from $52.96 \%$ to $62.46 \%$ ), represented mainly by linolenic $(22.15 \%)$ and oleic $(19.98 \%)$ acid, were predominantly present only in samples originating from mares of the Wielkopolski breed. In milk of mares of Konik Polski, saturated fatty acids appeared to predominate $(51.95 \%$ and $52.95 \%)$ in the early and mid lactation, whereas unsaturated fatty acids $(62.28 \%)$ predominated in the late lactation. In the case of milk samples of the Polish Cold-Blooded mares, saturated fatty acids (represented mainly by palmitic acid) were observed to prevail in the early and late lactation $(55.77 \%$ and $61.31 \%)$, whereas unsaturated fatty acids (52.20\%) were found to negligibly prevail in the mid lactation. The study confirmed that fatty acid composition was determined by the period of lactation and breed of the mares.
\end{abstract}

Keywords: fatty acids composition; mare milk; lactation, Polish Cold-Blooded, Wielkopolski, Konik Polski 


\section{Introduction}

During lactation, the composition of milk of mammals is subject to rapid changes, upon which milk becomes an ideal food for an infant. These changes refer both to macro- and microelements as well as the quantity and quality of protein and lipid substances and saccharides. Out of a variety of mammal species, the milk of mares has raised special interest due to the similarity of its chemical composition to that of human milk (Cieśla et al. 2009, Drogoul et al. 1992). Though in Poland this milk is used exclusively in the rearing of foals, some attempts have emerged to apply it as a raw material for the preparation of special food products for humans. Taking into account the relatively long period of lactation, considerable milk yield and substantial affinity of nitrogen compounds of mare milk to the respective compounds present in human milk, milk of mares may be considered as a raw material for the production of preparations substituting for natural food for infants (Smoczyński \& Tomczyński 1982, Csapo et al. 1995, Malacarne et al. 2002). Cow's milk has a different fatty acid composition compared to mare's milk (Pešek et al. 2005) and also other kinds of milk such as sow, goat, ewe and woman (Jahreis et al. 1999, Moduko \& Park 2007). Mares' milk has been considered as a possible substitute for cows' milk for allergic children (Businco et al. 2000, Curadi et al. 2001). The composition of dietary fatty acids is especially important for a young, developing human body. Food-originated fat is also likely to contain undesirable substances, e.g. trans isomers of fatty acids, which impair biosynthesis of physiologically-important long-chain polyunsaturated fatty acids (Pfeuffer 2001, Pordąb 1997).

Milk production and composition of fatty acids may change depending on the lactation stage, age, parity and nutrition (Wójtowski et al. 2001). There are many studies concerning the impact of lactation on the fat composition of mare milk (Haddad et al. 2011, Hoffman et al. 1998, Orlandi et al. 2003, Pikul \& Wójtowski 2008).

The above issues involve the necessity of continuing studies for the complete recognition of the quantitative composition of fatty acids of mare milk, which is becoming an important cognitive task. The results of such experiments not only have a cognitive aspect, but may also be exploited for practical purposes.

Our earlier investigations concerned the effect of the mare's breed on the fatty acid composition of milk fat (Pietrzak-Fiećko et al. 2009). The objective of this study was to determine the changes in fatty acid composition of mare milk from different breeds depending on the period of lactation.

\section{Material and methods}

The experiment was carried out on three groups of horses: 9 Polish Cold Blooded mares, 10 mares of Konik Polski and 10 mares of Wielkopolski Horse. Eighty seven mares' milk samples were analysed. The nutrition of mares was similar in research groups and in periods of lactation. The composition of the feeding ration included oat, hay and pasture grass. The analyses were carried out on samples of milk collected over a 6 -months period of lactation $-27,30$ and 30 samples were tested in the three different periods of lactation: early (0-2 month), mid (2-4 month) and late (4-6 month), respectively. 
The samples were obtained by hand milking. Mares' milk samples were collected in dark glass bottles. After a thorough mixing, a sample of about $250 \mathrm{~mL}$ was taken from the milk collected and fixed with hydrogen peroxide at a dose of ca. $1 \mathrm{~mL}$ per volume of milk taken. Until analysed, the milk samples were stored in a freezer at a temperature of $-21^{\circ} \mathrm{C}$.

The fat content of the milk was determined with the extraction method of Rose-Gottlieb (PN-57-A-86104). Fatty acid composition was estimated after having transformed the acids into methyl esters according to the IDF Standard 1999.

Analytical procedure: $0.05 \mathrm{~g}$ portion of milk fat was weighed into a test tube and dissolved in $2.5 \mathrm{~cm}^{3}$ of $\mathrm{n}$-hexane. Then, $0.1 \mathrm{~cm}^{3}$ of mixture $\left(11.2 \mathrm{~g} \mathrm{KOH}\right.$ in $100 \mathrm{~cm}^{3}$ of methanol) was added. After being tightly closed, the tubes were vigorously shaken for $1 \mathrm{~min}$. After another $5 \mathrm{~min}$, a $0.25 \mathrm{~g}$ portion of crystalline acid sodium sulphate $\left(\mathrm{NaHSO}_{4}\right)$ was added. After mixing, the tube was centrifuged at room temperature at about $1000 \mathrm{rpm}$.

This solution was subjected to a chromatographic analysis using an HP Agilent 6890 gas chromatograph (Agilent Tech. Inc., St. Clara, CA, USA), on a capillary column Supelcowex $(30 \mathrm{~m} \times 0.32 \mathrm{~mm}$ i.d., Sigma Aldrich, St. Louis, MO, USA) under the following conditions: flame-ionization detector, carrier gas-helium at a flow rate of $1.20 \mathrm{~cm}^{3} / \mathrm{min}$, separation temperatures: column - from $60^{\circ} \mathrm{C}(1 \mathrm{~min})$ to $175^{\circ} \mathrm{C}$ at a gradient of $8{ }^{\circ} \mathrm{C} / \mathrm{min}$, detector $-250^{\circ} \mathrm{C}$ and a sample injector with $100: 1$ division $-225^{\circ} \mathrm{C}$. Picks were identified based on a comparative analysis with retention times of the standards of fatty acid methyl esters of known composition.

The results are given as arithmetic mean and standard deviation. Examined was the influence of two factors: stage of lactation (3 levels: early, mid, late) and mare's breed (3 levels: Wielkopolski Horse, Konik Polski, Cold Blooded Horse). Statistica 9 PL software (StatSoft, Inc. Tulsa, OK, USA) was used for data analysis. The order to estimate the influence of this factors multi-factor Anova was applied. Duncan's test was used to compare the differences for significance level $P=0.05$.

\section{Results and discussion}

The results presenting the fatty acid composition in milk fat of mares of different breeds in the early, mid and late period of lactation are shown in Table 1.

In all samples of mare's milk, regardless of the breed and the stage of lactation, acid $C_{6: 0}$ was found in trace amounts. The Polish Cold-Blooded mares were characterised by higher contents of caprylic acid $\left(C_{8: 0}\right) 4.93 \%$, capric acid $\left(C_{10: 0}\right) 1.27 \%$, lauric acid $\left(C_{12: 0}\right) 10.41 \%$ and myristic acid $\left(\mathrm{C}_{14: 0}\right) 8.27 \%$ in the early period of lactation in comparison tothe Wielkopolski horse and Konik Polski. Milk samples from the Polish Cold-Blooded mares had the highest concentrations of $C_{8: 0}$ and $C_{10: 0}$ acid in the early lactation period. However, their concentrations decreased to a significant extent in the mid and late periods. In the case of this breed, concentrations of $C_{8: 0}$ and $C_{10: 0}$ acids in milk samples collected in the 5th and 6th month were higher by over $50 \%$ compared to the other breeds analysed in the study.

In the early and late lactation, milk of Konik Polski mares contained similar concentrations of $\mathrm{C}_{8: 0}$ and $\mathrm{C}_{10: 0}$ acid, whereas in the late lactation the concentration of caprylic acid was found to decrease approx. two times (from $3.50 \%$ to $1.79 \%$ ) and that of capric acid over three times (from $7.70 \%$ to $2.35 \%$ ). 


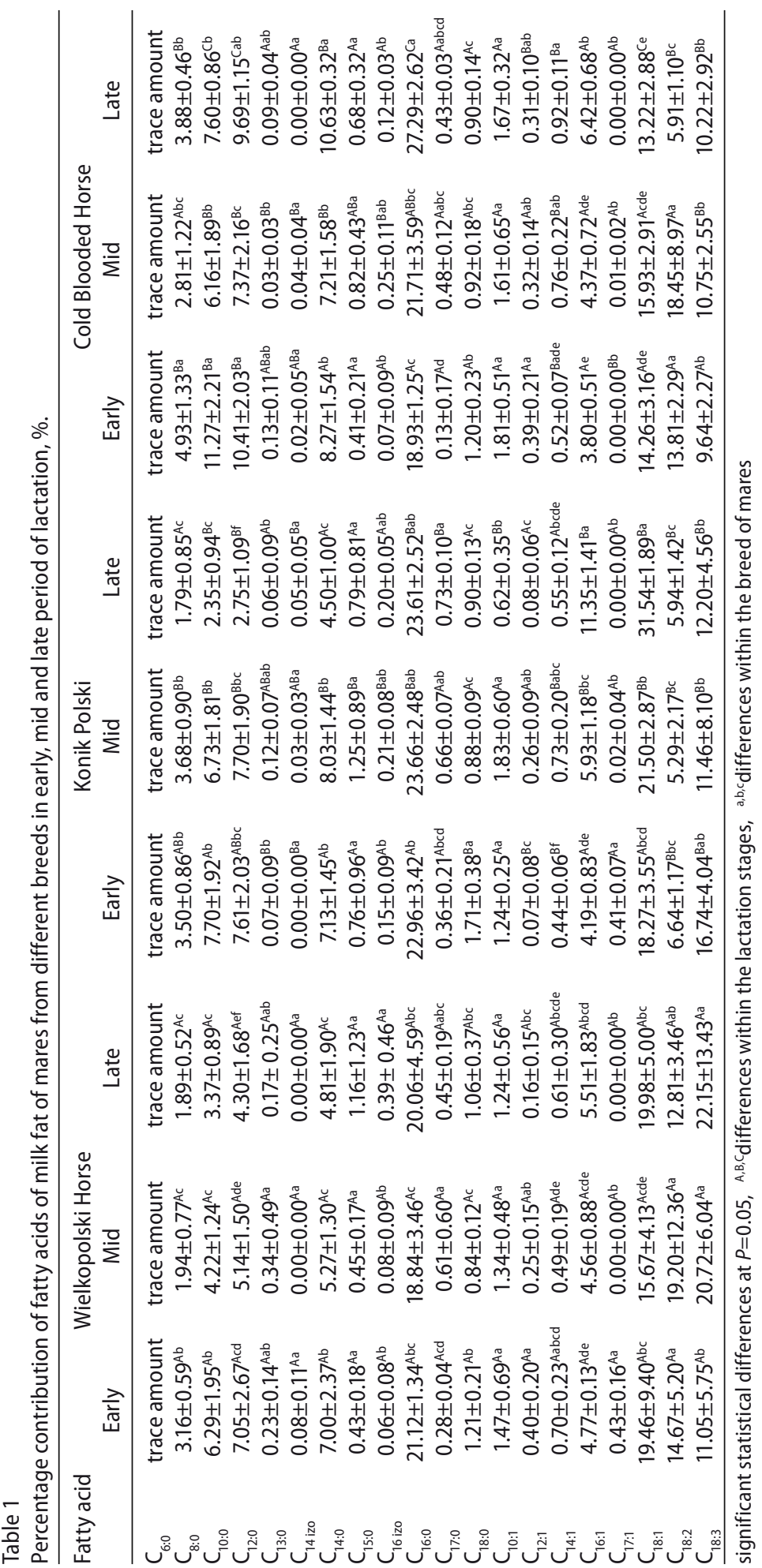


The content of $\mathrm{C}_{12: 0}$ acid ranged from $10.41 \%$ to $7.37 \%$ in Cold Blooded Horse's milk samples, from $7.70 \%$ to $2.75 \%$ in Konik Polski's and from $7.05 \%$ to $4.30 \%$ in Wielkopolski Horse's. Statistical differences were determined in the case of the content of $C_{12: 0}$ acid in studied breeds.

Analysing the level of saturated fatty acids (from $C_{13: 0}$ to $C_{16: i z 0}$ ) in milk fat of mares of the Wielkopolski breed) in every period of lactation, a higher content of $C_{13: 0}$ acid (tridecanoic) was observed in contrast to the other two breeds examined. Similar observations were made for the content of $C_{14: i z o}$ acid, where the highest concentration ( $0.08 \%$ ) ever reported in milk of the Wielkopolski breed mares in early lactation was measured, but there were no statistical differences.

The content of $C_{15: 0}$ acid ranged from $0.43 \%$ to $1.16 \%$ in Wielkopolski Horse's milk samples, from $0.76 \%$ to $1.25 \%$ in Konik Polski's and from $0.41 \%$ to $0.82 \%$ in Cold Blooded Horse's. Statistical differences were not determined in the case of content of $C_{15: 0}$ acid in all studied breeds.

Analyses of the level of higher saturated fatty acids (from $C_{16: 0}$ to $C_{18: 0}$ ) demonstrated the greatest contribution of palmitic acid ( $\left.C_{16: 0}\right)$ accounting for: $27.29 \%$ in milk fat of Cold-Blooded mares in the late period of lactation to $18.84 \%$ in milk fat of mares of the Wielkopolski breed in mid lactation. The content of $C_{16: 0}$ in Konik Polski breed milk samples was that of $22.96 \%$ in the early lactation to $23.61 \%$ in the late lactation. It is worth to notice that the milk of the Konik Polski breed in the early lactation distinguished in terms of the content of five acids $\left(C_{15: 0^{\prime}} C_{16: i z 0^{\prime}}, C_{16: 0^{\prime}} C_{17: 0}\right.$ and $\left.C_{18: 0}\right)$ which were higher in comparison to the milk of both Wielkopolska and Polish Cold-Blooded mares breeds.

Investigations conducted by Kulisa on mares of Arabian, Małopolska and Hucul breeds also demonstrated high and similar levels of palmitic acid $\mathrm{C}_{16: 0}$ during the lactation, i.e. $27.85 \%$ in Arabian mares, $26.17 \%$ in Małopolska breed mares and $31.60 \%$ in Hucul breed mares (Kulisa 1998). Similarly high concentrations of palmitic acid were observed by Jaworski et al. (1982). It should be emphasized that significantly higher concentrations of palmitic acid $\mathrm{C}_{16: 0}$ were reported by these authors only in the first days of lactation. In subsequent days, its level ranged from $19 \%$ to $21 \%$. Apart from palmitic acid, high concentrations were also recorded in the case of lauric acid $\mathrm{C}_{12: 0}$ and myristic acid $\mathrm{C}_{14: 0}$. In milk of mares of the Wielkopolski and Konik Polski breeds, their levels were observed to decrease in the entire period of lactation. In turn, milk fat of the Polish Cold-Blooded mares was characterised by reduced levels in the mid period followed by increasing concentrations in the late lactation.

Among the unsaturated fatty acids monounsaturated were identified: $C_{10: 11^{\prime}} C_{12: 11^{\prime}} C_{14: 1^{\prime}} C_{16: 11^{\prime}}$ $\mathrm{C}_{17: 1^{\prime}} \mathrm{C}_{18: 1}$ and polyunsaturated: $\mathrm{C}_{18: 2^{\prime}} \mathrm{C}_{18: 3^{\prime}}$.

The content of $\mathrm{C}_{10: 1}$ acid ranged from $1.47 \%$ in the early lactation to $1.24 \%$ in the late lactation in Wielkopolski Horse's milk samples, from $1.83 \%$ in the mid lactation to $0.62 \%$ in the late lactation in Konik Polski's and from $1.81 \%$ (early lactation) to $1.61 \%$ (mid lactation) in Cold Blooded Horse's.

In milk of mares of the Wielkopolski and Cold Blooded breeds, the levels of $C_{12: 1}$ were observed to decrease in the entire period of lactation. In the case of the Konik Polski breed the content of $\mathrm{C}_{12: 1}$ was higher in the mid period and lower in the other periods of lactation.

The content of $C_{14: 1}$ in the mares' milk fat of all breeds was that of $0.44 \%$ to $0.92 \%$. The content of $C_{16: 1}$ in milk of mares of all breeds increases with the period of lactation - the 
highest growth was observed in the case of Konik Polski mares' milk - from $4.19 \%$ in the early period to $11.35 \%$ in late period of lactation.

The highest concentration of oleic acid $\mathrm{C}_{18: 1}$ was observed in milk of the Konik Polski mares, it ranged from $18.27 \%$ in the early lactation to $31.54 \%$ in the late lactation. In this case statistical differences were determined.

In turn, milk of mares of the Wielkopolski breed was characterised by the highest concentrations of linolenic acid $C_{18: 3}\left(22.15 \%\right.$ - late lactation) as well as linolenic acid $C_{18: 2}$ (19.20\% - mid lactation).

The lowest content of saturated fatty acids in the early lactation was stated in the milk of mares of the Wielkopolski breed (46.95\%), whereas the highest was in that of Polish ColdBlooded horses (55.77\%). Milk of mares of the Konik Polski breed was found to contain $51.95 \%$ of saturated fatty acids (Figure 1).

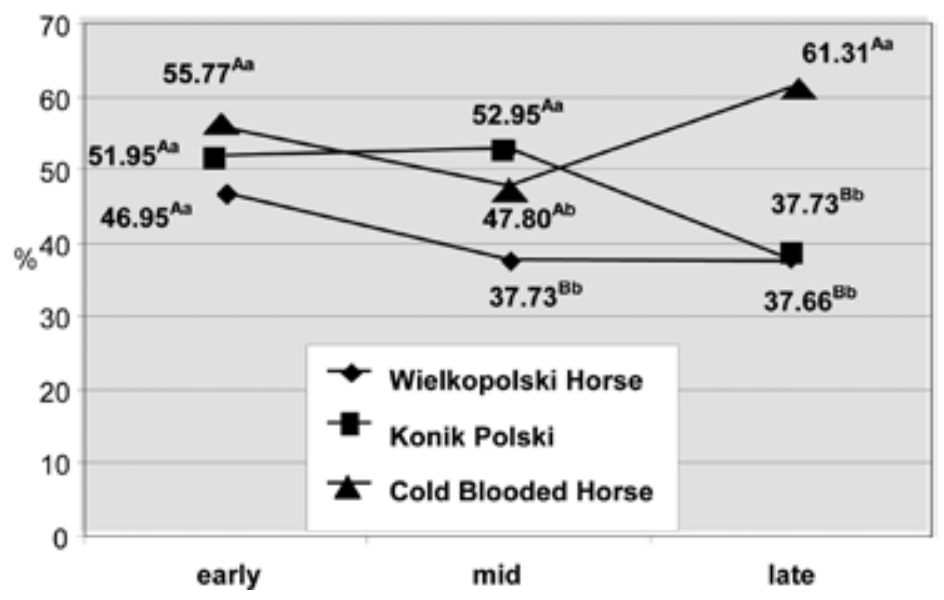

significant statistical differences at $P=0.05$, $\mathrm{A}, \mathrm{B}, \mathrm{C}$ differences within the lactation stages, $\mathrm{a}, \mathrm{b}, \mathrm{c}$ differences within the breed of mares

Figure 1

Saturated fatty acid in mares' milk in different periods of lactation

In the mid period of lactation the lowest concentrations of saturated fatty acids were observed in milk of mares of the Wielkopolski breed (37.73\%) and the highest one in that of mares of the Konik Polski breed (52.95\%). Milk of the Cold-Blooded mares was found to contain $47.80 \%$ of saturated fatty acids.

The total content of saturated fatty acids in milk of mares of the Wielkopolski and Konik Polski breeds was observed to decrease along with the following period of lactation - in the late by $20 \%$ and $27 \%$, respectively. In the case of the Polish Cold-Blooded breed, the content of saturated fatty acids in milk was observed to decrease slightly in the mid period of lactation and to increase by ca. $10 \%$ in the late of lactation.

The highest content of saturated fatty acids in the late lactation was observed in milk of the Cold-Blooded mares (61.31\%), whereas their concentrations in milk of mares of the Wielkopolski and Konik Polski breeds accounted for $37.66 \%$ and $37.73 \%$, respectively. The highest content of saturated fatty acids in the late lactation in milk of the Cold-Blooded mares may be caused by high concentrations of palmitic acid $C_{16: 0}(27.29 \%)$, as well as myristic acid $C_{14: 0}(10.63 \%)$ and lauric acid $C_{12: 0}(9.69 \%)$. 
Statistical differences were determined in mare's milk fat of Wielkopolski breed in the mid period of lactation. In milk fat from Cold Blooded breed in the late period of lactation statistical differences were determined in the content of saturated fatty acids. Statistical differences within the breeds of mares were determined in all studied breeds in the case of saturated fatty acids.

Unsaturated fatty acids in mares' milk fat in different periods of lactation were shown in Figure 2. The highest content of unsaturated fatty acids in the early lactation was determined in milk of mares of the Wielkopolski breed $(52.95 \%)$, whereas the lowest was in milk of the Polish Cold-Blooded mares (44.23\%). The mean content of unsaturated fatty acids in milk fat of mares of the Konik Polski breed reached $48.05 \%$. In the group of monounsaturated fatty acids, the highest concentration was reported for oleic acid $\mathrm{C}_{18: 1}$. Its content in milk of mares of the Wielkopolski, Konik Polski and Polish Cold-Blooded breeds accounted for $19.46 \%$, $18.27 \%$ and $14.26 \%$, respectively.

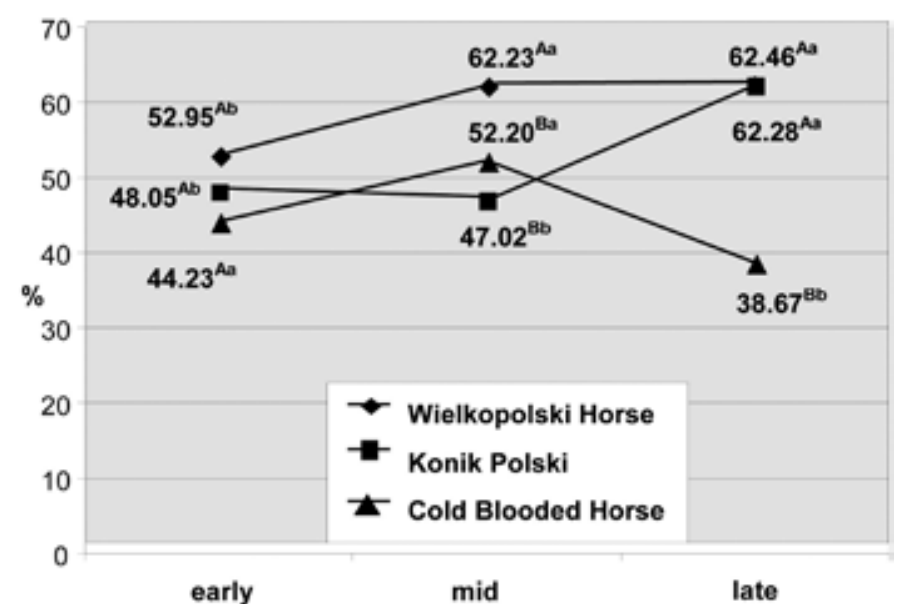

significant statistical differences at $P=0.05$, $A, B, C$ differences within the lactation stages, $\mathrm{a}, \mathrm{b}, \mathrm{c}$ differences within the breed of mares

Figure 2

Unsaturated fatty acids in mares' milk in different periods of lactation

In the mid period of lactation, the content of total unsaturated fatty acids appeared to be the highest in milk of the Wielkopolski breed mares (62.23\%) and the lowest in milk of mares of the Konik Polski breed (47.02\%).

In the late lactation, the total content of unsaturated fatty acids was found to be the lowest in milk of mares of the Polish Cold-Blooded breed (38.67\%), whereas in milk of the other two breeds under study it reached ca. $62 \%$.

The sum of unsaturated fatty acids increased in milk of mares of the Wielkopolski and Konik Polski breeds by ca. $18 \%$ and $30 \%$, respectively, in the late of lactation. Contrasting results were determined for milk of the Cold-Blood mares, for which the content of these acids decreased by ca. $13 \%$ in the late of lactation. The samples originating from the Wielkopolski breed mares were characterised by a decrease in the level of unsaturated fatty acids over the lactation period.

In the case of unsaturated fatty acids statistical differences within the lactation stages were determined in milk fat of the Wielkopolski breed in the mid period of lactation and 
in the milk of the Cold Blooded breed in the late period of lactation. Statistical differences within the breeds of mares were determined in all studied breeds in the case of unsaturated fatty acids.

A study by Pietrzak-Fiećko et al. (2007) demonstrated that in the early lactation human milk contained on average $46.6 \%$ of saturated fatty acids and $53.39 \%$ of mono- and polyunsaturated fatty acids. Results obtained in the reported study showed that in the same period of lactation, milk of mares of the Wielkopolski breed was characterised by highly similar ratios of fatty acids, i.e. $46.95 \%$ of saturated and $52.95 \%$ of unsaturated fatty acids. This may be a fine argument for applying mare milk as a raw material for the production of preparations substituting for infant formula.

According to Malacarne et al. (2002), mare's milk could be more suitable than cow's milk for human, because the saturated fatty acid content is similar in mare and human milk. Mare milk had the highest content of medium-chain saturated fatty acids $\left(\mathrm{C}_{8: 0}-\mathrm{C}_{14: 0}\right)(38.28 \%)$ and the lowest of long-chain saturated fatty acids $\left(C_{15: 0}-C_{20: 0}\right)(18.28 \%)$ compared to human milk ( $14.17 \%$ and $28.18 \%$, respectively). The average content of unsaturated fatty acids $-42.85 \%$ in mare and $45.20 \%$ in human milk fat - is higher than in cow's milk fat (Malacarne et al. 2002).

The presented analysis of fatty acid composition of milk fat of mares of different breeds: Wielkopolski Horse, Konik Polski and Cold-Blooded Horse in particular periods of lactation: early (0-2 month), mid (2-4 month) and late (4-6 month) demonstrates the influence of these factors. Studies have confirmed that both the breed and the stage of lactation have an influence on the fatty acid composition in mare's milk fat.

\section{References}

Businco L, Giampietro PG, Lucenti P, Lucaroni F, Pini C, Di Felice G, lacovacci P, Curadi C, Orlandi M (2000) Allergenicity of mare's milk in children with cow's milk allergy. J Allergy Clin Immunol 105, 1031-1034

Cieśla A, Palacz R, Janiszewska J, Skórka D (2009) Total protein, selected protein fractions and chemical elements in the colostrum and milk of mares. Archiv Tierz 52, 1-6

Csapó J, Stefler J, Martin TG, Makray S, Csapó-Kiss Zs (1995) Composition of mares' colostrum and milk. Fat content, fatty acid composition and vitamin content. Int Dairy J 5, 393-402

Curadi MC, Giampietro PG, Lucenti P, Orlandi M (2001) Use of mare milk in pediatric allergology. In: 14th Proc ASPA Congress, Firenze, Italy, 647-649

Drogoul C, Prevost H, Maubois JL (1992) [Mare's milk, a product, develop a sector? What's new in matters of research studies on the horse?] In : Proceedings 18éme Journée d'Etude, CEREOPA (editor), Paris, France, 37-51 [in French]

Haddad I, Mozzon M, Strabbioli R, Frega NG (2011) Fatty acid composition and regiodistribution in mare's milk triacylglycerols at different lactation stages. Dairy Sci Technol 91, 397-412

Hoffman RM, Kronfeld DS, Herbein JH, Swecker WS, Cooper WL, Harris PA (1998) Dietary Carbohydrates and Fat Influence Milk Composition and Fatty Acid Profile of Mare's Milk. J Nutr 128, 2708-2711

IDF Standard (1999) Milk fat: Preparation of fatty acid methyl esters, 182

Jahreis G, Fritsche J, Möckel P, Schöne F, Möller U, Steinhart H (1999) The potential anticarcinogenic conjugated linoleic acid, cis-9, trans-11 $\mathrm{C}_{18: 2^{\prime}}$ in milk of different species: cow, goat, ewe, sow, mare, woman. Nutr Res $19,1541-1549$

Jaworski J, Jaworska H, Tomczyński R, Smoczyński S (1982) [Fatty acid composition in mare milk in period of lactation]. Zesz Nauk ART Olsztyn Technol Żywn 17, $85-94$ [in Polish] 
Kulisa M (1998) [The content of selected amino-acids and fatty acids in mare's milk from arabic, małopolski, hucarski breeds]. Roczn Nauk Zootech 4, 79-89 [in Polish]

Moduko CO, Park YW (2007) Modification of fatty acid and sterol composition of caprine milk for use as infant formula. Int Dairy J 17, 1434-1440

Malacarne M, Martuzzi F, Summer A, Mariani P (2002) Protein and fat composition of mare's milk: some nutritional remarks with reference to human and cow's milk. Int Dairy J 12, 869-877

Orlandi M, Goracci J, Curadi MC (2003) Fat Composition of Mare's Milk with Reference to Human Nutrition. Annali della Facoltà di Medicina veterinaria 56, 97-105

Pešek M, Špička J, Samková E (2005) Comparison of fatty acid composition in milk fat of Czech Pied cattle and Holstein cattle. Czech J Anim Sci 50, 122-128

Pfeuffer M (2001) Physiologic effects of individual fatty acids in animal and human body, with particular attention to coronary heart disease risk modulation. Arch Tierz 44, 89-98

Pordąb Z (1997) [Lipids in modified milk for infants.] Przem Spoż 8, $33-35$ [in Polish]

Pietrzak-Fiećko R, Borejszo Z, Smoczyński S (2007) Fatty acid composition in human milk, UHT cow's milk and infant formulas. Milchwissenschaft 62, 380-383

Pietrzak-Fiećko R, Tomczyński R, Świstowska A, Borejszo Z, Kokoszko E, Smoczyńska K (2009) The effect of mare's breed on the fatty acid composition of milk fat. Czech J Anim Sci 54, 403-407

Pikul J, Wójtowski J (2008) Fat and cholesterol content and fatty acid composition of mare's colostrums and milk during five lactation months. Livest Sci 113, 285-290

Smoczyński S, Tomczyński R (1982) [A study of chemical composition of mare milk. I. Chemical composition of mare milk in first ten days of lactation]. Zesz Nauk ART Olsztyn Technol Żywn 17, 77-84 [in Polish]

Wójtowski J, Danków R, Gut A, Pikul J, Slósarz P, Stanisz M, Steppa R (2001) Fatty acid composition and cholesterol content of sheep and goat milk fat during lactation. Arch Tierz 44 (Special Issue), 299-308 [in German] 